\title{
LOS DONES DE CUQUI TODOS LOS PRESENTES AUTOBIOGRÁFICOS
}

\author{
Anahi Rocio Pochettino \\ Universidad Nacional de Córdoba / CONICET
}

\begin{abstract}
RESUMEN
Este artículo interpela un breve corpus de obras de la escritora y performer argentina Cuqui: KIKI (2008), KIKI 2 (2012) y la Poesía Completa de Natsuki Miyoshi (2012), a partir de la tensión entre presente, don y autobiografía. La escritura de Cuqui parte de una ética del deseo, se apropia de la Metagenealogía y la Psicomagia de Alejandro Jodorowsky, como métodos artísticoliterarios para redisponer la construcción de la propia autobiografía. La firma Cuqui ( $\mathrm{y}$ todos sus heterónimos) da lugar $\mathrm{y}$ visibiliza la irrupción del nombre como crédito del sí mismo que se explora, examina y crea como parte de una "tecnología del yo". En este sentido, el artículo se orienta a responder de qué manera Cuqui es el don o presente absoluto de la escritura autobiográfica.
\end{abstract}

PALABRAS CLAVE: Literatura argentina reciente. Cuqui. Presente. Don. Autobiografía.
ABSTRACT

This article interpellates a short corpus of texts of the writer and performer argentine Cuqui: KIKI (2008), KIKI 2 (2012) and the Complete Poetry of Natsuki Miyoshi (2012), from the tension between: present, gift and autobiography. Cuqui's writing comes from an ethics of desire, appropriates Alejandro Jodorowsky's Metagenealogía and Psicomagia, as artistic and literary methods to rearrange the construction of autobiography. Cuqui signature (and all heteronyms) leads and visibility the emergence of the name as credit of itself that is explored, discussed and created as part of a "technology of the self". In this sense, the article aims to answer how Cuqui is the gift or absolute present of autobiographical writing.

KEYWORDS: Recent Argentine literature. Cuqui. Present. Gift. Autobiography.

Recebido: 24/06/2013

Aprovado: 30/08/2013

Anahi Rocio Pochetinno < rocio.pochettino@gmail.com> es doctoranda en Letras por la Universidad Nacional de Córdoba. 


\title{
LOS DONES DE CUQUI TODOS LOS PRESENTES AUTOBIOGRÁFICOS
}

\author{
Anahi Rocio Pochettino
}

DEVENIR MITO. LA AUTOBIOGRAFÍA COMO DON

Nicolás Rosa, al referirse a la "teorética autobiográfica”, proponía la simultaneidad y solidaridad de acto y texto en su composición y formalización. Afirmaba que "el acto genera una temporalidad y una escritura de esa temporalidad, una tramitación imaginaria de construcción de una personalidad o de un carácter [...] sobre el Yo que los soporta." ${ }^{1}$ El acto autobiográfico emerge en el complejo de la escritura de esa temporalidad sobre procesos de memoria, recuerdo y olvido, sobre el acto de memoración y rememoración. La singularidad que marca a la autobiografía es el hecho de que el yo que instaura el acto autobiográfico tiene como premisa "la extrañeza del sujeto que se ve como otro de sí mismo [...] su propio yo como otro, como él, como objeto, en el propio espacio de su escritura." ${ }^{2}$ Esta extrañeza irrumpe en el desfasaje temporal que implica la asunción de la inscripción. Jacques Derrida señalaba que la inscripción implica la no-presencia actual o empírica del signatario, pero que al mismo tiempo "señala y recuerda su haber estado presente en un ahora pasado, que será todavía una ahora futuro, por tanto un ahora en gene-

1 ROSA, Nicolás. El arte del olvido y tres ensayos sobre mujeres. Rosario: Beatriz Viterbo, 2004, p. 46.

2 Ibídem, p. 51. 
ral, en la forma trascendental del mantenimiento." ${ }^{3}$ Esto supone asumir la forma de la iterabilidad y reconocer que es la inscripción la que crea al signatario en tanto "se abre un crédito, su propio crédito, de sí misma a sí misma" 4 , como acto o golpe de fuerza, de escritura, dándole lugar. Lo que atraviesa la lectura derrideana es la escena del Nietzsche de Ecce Homo, el cual se coloca con su nombre y cuerpo en un primer plano, aún ante el desfile de máscaras y seudónimos. A partir de las citas "Wie man wird, was man is y Wer ich bin", comprendidas como formas de dejar testimonio de sí, como modos de vivir del propio crédito abierto por el yo y otorgado a sí mismo, es que Derrida plantea en términos nietzscheanos que la identidad no se debe a un contrato establecido con los contemporáneos, sino al contrato inaudito y deuda que el yo suscribe consigo. La interpelación de Derrida al problema nietzscheano del wie man wir, was man ist nos permite discutir en las autobiografías cómo "la firma inventa al signatario"5, cómo antes del texto no existe signatario, y cómo el texto es productor y garante de la propia firma. Derrida plantea que llegado al final de su firma es cuando el signatario está autorizado a firmar, lo que define una retroactividad por la cual es "su primera firma [la que] lo autoriza a firmar." ${ }^{2}$ La representatividad está legitimada a posteriori por la firma, en otras palabras, el derecho a firmar se da en tanto ya me lo he atribuido: "Me habré dado un nombre y un 'poder', entendido en el sentido de poder firmar por delegación de firma."7 Esto plantea la inadecuación de un presente a sí mismo, la implicancia de una huella y cómo la firma se da un nombre. En relación con el crédito abierto en nombre del yo - y necesariamente en nombre de otro - , no puede saberse nunca, a partir del presente y los saberes presentes, si se será honrado alguna vez. En este sentido, la autobiografía - vida que vive y se cuenta a sí -, comprendida en el contrato y

3 DERRIDA, Jacques. Firma, acontecimiento y contexto. In: Márgenes de la filosofía. Trad. Carmen G. Marín. Madrid: Cátedra, 1998, p. 370.

4 DERRIDA, Jacques. Otobiografías. La enseñanza de Nietzsche y la política del nombre propio. Trad. Horacio Pons. Buenos Aires: Amorrortu, 2009, p. 18.

5 Ibídem, p. 17.

6 Ibídem, p. 18.

7 Ibídem, p. 18. 
deuda consigo mismo, es sólo un prejuicio. Toda anticipación (Vorurteil) sólo podrá ser verificada en el momento en que el portador del nombre esté muerto. En tanto el yo se cuenta su vida a sí mismo como destinatario único de la narración, hace autobiográfico al relato. No porque el firmante cuenta su vida, el retorno de su vida pasada, sino porque este relato es un don a sí mismo ("Und so erzähle ich mir mein Leben"). En tanto don, el relato autobiográfico se destina a sí en el crédito del eterno retorno, sigue siendo un prejuicio en el "hasta aquí" o "hasta ahora". Con ello da presente, abre el tiempo del relato. Cuando Derrida en Dar (el) tiempo vuelve sobre el Ensayo sobre el don de Marcel Mauss, lo que hace es interpelar al don como don que se da en la medida en que se da (el) tiempo, desprendiendo de ello que lo que diferencia el don de cualquier otra operación de intercambio puro y simple, es que éste es don y petición de tiempo. Con la solicitud se define un plazo, un ritmo o cadencia. Lo que es dado debe ser restituido, pero no de manera inmediata ni al instante, sino que debe sostenerse en un tiempo, elaborar una espera del dar y tomar(se) (el) tiempo. Cuando el don es el yo, dicho mantenimiento en el tiempo del relato autobiográfico es el que abre el crédito a sí.

Cuqui problematiza la temporalidad del don autobiográfico a partir de ciertos procedimientos de inscripción del nombre. Desde 1999 la escritora, artista visual, performer y tarotista, ha publicado, a través de distintos sellos editoriales y en algunas ocasiones recurriendo a la edición de autor, una serie de libros de poesía y narrativa con el heterónimo Cuqui, otros de poesía como Natsuki Mishosi, Karen Smith, y ensayo como Charlotte von Mess. ${ }^{8}$

8 Nuestro registro cuenta con los siguientes libros y sus correspondientes firmas: como Cuqui, firmó los libros de poesía Cuando explota un globo (Ed. del Boulevard, 1999), lavados vaginales (Vox, 2003), Naranja verde amarillo/naranja verde rojo (Ed. Huácala Capirote, 2002), Singlista (Coedición Ferreyra/El cíclope, 2006), Actriz de reparto (La creciente, 2004); libros de pensamientos A mí me picó una araña (Eloísa cartonera, 2005), Fruta fermentada (Coedición, La creciente/Huácala Capirote, 2006); los libros de narrativa Masturbación (Eloísa Cartonera, 2005), KIKI (Ed. Huácala Capirote, 2008), KIKI 2 (Editorial Nudista, 2012) y Desierto dividido en centímetros por piedras (La Sofía Cartonera, 2012). Como Natsuki Mishosi, Poesía completa (2009-2010) (Babel, 2012) y como Karen Smith, He said the last word in a car (inédito). 
La mayoría de estos libros han sido parte de un trabajo interdisciplinar, convergiendo en la experiencia de escritura, edición y presentación, el teatro y la performance, la fotografía, las ilustraciones, y el arte-video. Por citar algunos ejemplos: lavados vaginales (2003) y Singlista (2006) son libros que integran poesía y dibujos de la autora; Fruta Fermentada (2006) combinó ilustraciones, autorretratos fotográficos, un stock limitado de muñecas artesanales, entrevistas de lectores y una performance de seis horas de duración sin cortes íntegramente registrada por fotógrafos; y para la presentación de Informes a la crema (2011), uno de los libros que compone la Poesía Completa (2012) de Natsuki Mishosi, se invitó a los asistentes a participar de un acto psicomágico de sanación de los libros utilizando telas blancas, talco y pintura dorada. Los libros de Cuqui devienen así artefactos complejos que interpelan simultáneamente las tradiciones de disciplinas diversas y provocan una sospecha en la disposición de esa interpelación. Dis-poner es reactivar el gesto y el archivo. Dis-poner para re-atribuir una función disparatada, para no hacer obra, para visibilizar en el prefijo la negación de la obra como resultado final de un proceso, en tanto que dis-puesto todo puede empezar siempre. Cuqui inscribe la dis-posición, la des-composición, la des-organización, la in-operación, y estas inscripciones acontecen siempre desde estrategias ligadas al nombre, al deseo, a lo autobiográfico. El nombre propio, por cual ya opera un desajuste temporal ligado a la reproductibilidad de la firma y al crédito que se abre a sí mismo, se re-dis-pone con esta artista a una vorágine de rescritura: el nombre nunca está en el origen de sus inscripciones, sino en el futuro. En Cuqui irrumpe Kiki, irrumpe Natsuki Miyosi, irrumpe Karen Smith; y Cuqui nunca es el origen, es solo el gesto de una mascarada, la pervivencia del intento por suspender el origen, la relación de consecuencia entre el antes y el después, entre originales y copias. En este sentido, Cuqui siempre adviene re-dis-poniendo la arché como meta, reinventando el oficio: “Cada nombre condensa un personaje, son heterónimos. La particularidad de Cuqui es que es heterónimo como consecuencia de la aparición de los otros 
seres, porque Cuqui soy yo ¿o es el nombre que compartimos?"9 La escritora instala el interrogante como "sospecha genealógica" respecto del propio mito.

La relación entre autobiografía, autoficción y mito, ha sido trabajada por José Amícola para pensar las operaciones de inscripción de nombre en escritores como Copi, Gombrowicz, o Borges. En Estéticas bastardas, Amícola plantea que la autoficción, como forma literaria posmoderna, da lugar a un uso descarado de los nombres propios reales, antes confinados a las novelas autobiográficas, los cuales aparecen en convivencia paradojal con un "pacto novelesco". La relación entre mito y autoficción se hallaría precisamente en "la obsesión por dar los nombres propios, la perentoria manía de nombrar y nombrar por exceso de apelación."10 En esta perspectiva, se recupera principalmente la teoría del mito de Hans Blumenberg, por la cual se visibiliza la necesidad de toda sociedad de dar nombre a las cosas que teme para extraerlas del caos y poder así crearlas: "el mito en la conciencia mitológica es análogo al nombre propio, porque se le atribuye esencia ontológica."11 El acto de dar nombre al caos, comprendido desde la perspectiva de articulación entre autoficción y mito, es el que inscribe al escritor como instaurador de firma mediante la cual no solo se crea a sí mismo en la posibilidad iterativa de reproducir su nombre, sino que se configura como demiurgo creador de mundo. Amícola sigue a Blumenberg en la consideración del mito como reelaboración constante, y en la imposibilidad de diferenciar en el mito, el trabajo ejercido, del resultado obtenido de él. La literatura deviene, entonces, esta permanente reelaboración o "pregnancia simbólica". Desde otra perspectiva, aunque también valoradora de la productividad y reelaboración mítica, Paul Ricoeur asumió necesario la adopción de una actitud de demitologización, que involucra el doble aspecto de desmitificación y antropogénesis, consistente en la destrucción de la racionalización posterior del mito, para la recuperación de su fondo enigmático, y desvelamiento del hombre

\footnotetext{
9 CUQUI. Entrevista para el Museo Caraffa, inédito.

10 AMÍCOLA, José. Estéticas bastardas. Buenos Aires: Biblos, 2012, p. 14.

11 Ibídem, p. 19.
} 


\section{\begin{tabular}{r|r} 
anahi rocio pochettino & $\mathbf{6 8}$
\end{tabular}}

como productor de su existencia. Esto es clave para comprender el desarrollo de una razón imaginativa consistente en la revelación del deseo de existir como estructura primaria de la ética. ${ }^{12}$

La escritura de Cuqui parte de una ética del deseo, en el sentido en que la apropiación de la Psicomagia y la Metagenealogía, como métodos artísticoliterarios para redisponer la construcción de la propia autobiografía en tanto mito, asume la imaginación como forma crítica respecto de obligaciones y desarrolla una dialéctica de la acción como relación entre el deseo de ser y su efectivización en la obra. En este sentido, si la firma en Cuqui actúa como inscripción que emerge de la razón imaginativa, entonces es posible preguntarnos respecto de los modos en que: la firma da lugar y visibiliza la irrupción del nombre como crédito del sí mismo que se explora, examina y crea como parte de una "tecnología del yo"; y la firma es el don o presente absoluto, ya que da lugar al origen en el futuro en tanto la revisión metagenealógica del diario personal promete el yo y la escritura por venir; y de esta manera, la firma deviene una espera de sí.

Cómo dAR(SE) NOMBRES: LA PSICOMAGIA EN CUQUi COMO INTERPELACIÓN MíTICOAUTOBIOGRÁFICA DEL PRESENTE

12 Ricoeur procede a revelar el pasaje "de la moral de la obligación a una ética del deseo de ser o del esfuerzo para existir" (RICOEUR, Paul. El conflicto de las interpretaciones. Ensayos de hermenéutica. Trad. Alejandrina Falcón. Buenos Aires: FCE, 2003, p. 309). Este desplazamiento supone haber transitado desde un divorcio de la obligación kantiana, interpretada como acusación, para convertirse en el deseo por perseverar en el ser spinoziano. El método de desmitologización, cuando es aplicado al tema de la acusación, revela la falsa trascendencia del imperativo, permitiendo la apertura al descubrimiento de la esencia de la ética en nuestro deseo de ser y nuestro esfuerzo por existir. En esto, Ricoeur se apoya en el trabajo genealógico regresivo freudiano respecto de Kant: "Donde Kant utiliza un análisis categorial, Freud recurre a un análisis filológico que ejerce una acción de sospecha que desplaza el sentido aparente hacia otro sentido, disimulado por el primero. Así la 'buena conciencia' kantiana se transforma de juzgante en juzgada, y la obligación pasa a ser interpretada desde el deseo" (CRAGNOLINI, Mónica. Razón imaginativa, identidad y ética en la obra de Paul Ricoeur. Buenos Aires: Editorial Almagesto, 1993, p. 21). De esta manera, si el origen de la ética es, para Ricoeur, el deseo de existir, habría que estudiar de los mitos y símbolos que se generan a partir de ello como productos de la imaginación. 
La Psicomagia se vincula a la "terapia pánica" o "teatro efímero pánico" de Alejandro Jodorowsky. En Le Panique, Jodorowsky formuló sus concepciones teatrales y de proceso del efímero pánico, consistentes en la "liberación del edificio teatro" como posibilidad de acceso a la euforia pánica: "Puesto que lo efímero es una manifestación concreta, no se puede evocar en él problemas de espacio y de tiempo: el espacio tiene sus medidas reales y no puede simbolizar otro espacio: es lo que es en el instante mismo." 13 Por lo tanto, esta liberación refiere a una deconstrucción del espacio teatral que cuestione las delimitaciones actor/espectador dadas por las imposiciones del dispositivo arquitectónico a los movimientos corporales y gestuales:

Al eliminar al espectador en la fiesta pánica, se elimina automáticamente la "butaca" y la "interpretación" ante una mirada inmóvil. El lugar donde acontece "lo efímero" es un espacio no delimitado, de tal manera que no se sabe dónde comienza la escena y dónde comienza la realidad. ${ }^{14}$

Asimismo la temporalidad es revisada por el efímero pánico, afirmando la necesidad de un "tiempo real" que borre los límites entre personaje, persona y actor, que prescinda del ensayo y que irrumpa como acto único, sin repetición, articulado a materialidades perecederas que dieran cuenta de lo instantáneo y fugitivo de la vida. En este sentido, quien participa en el pánico es un exactor, quien ha eliminado de forma total el personaje y ya no actúa en una representación, puesto que su acción es la de "alcanzar a la persona que está siendo." 15 Jodorowsky considera que la participación pánica promueve en los espectadores-actores, es decir, en los exactores, la práctica de un acto teatral radical que pone en juego la interpretación del propio drama, la exploración del propio enigma íntimo.

La Psicomagia puede leerse como un devenir del efímero pánico, que consiste en un "programa de acción"16 que se desarrolla en una circunstancia

\footnotetext{
13 JODOROWSKY, Alejandro. Psicomagia. Madrid: Ediciones Siruela, 2004, p. 28-29.

14 Ibídem, p. 28.

15 Ibídem, p. 30.

16 Ibídem, p. 18.
} 
espacial y temporal única e irrepetible, orientado hacia un efecto terapéutico por vías de una acción creativa llevada a cabo en el ámbito real. Jodorowsky refiere que la terapia psicomágica parte de la actualización de una dificultad, de la concientización de la identidad y la propia actuación a través del tarot como técnica proyectiva y del análisis metagenealógico de lectura de árbol genealógico como búsqueda del origen del malestar. La "curación" psicomágica provendría de la ejecución de una acción concreta y creativa, pautada entre consultante y consultado, llevada a cabo en el ámbito real. En este sentido, el acto psicomágico es una apropiación de la performance de los curanderos o chamanes. Pero mientras que en esta, se obra por efectos de la "trampa sagrada" 17 embaucando al consultante, haciéndole experimentar una transformación interior que le permite captar el mundo desde la intuición más que desde la razón; la psicomagia proporcionaría una suerte de explicación al acto ritual, puesto que

en lugar de una creencia supersticiosa se necesita la comprensión del consultante. Él debe saber el porqué de cada una de sus acciones. El psicomago, de curandero pasa a ser consejero: gracias a sus recetas el paciente se convierte en su propio sanador. ${ }^{18}$

La confluencia de actos poéticos, teatrales, oníricos y mágicos, hace de la comprensión psicomágica una forma de la razón imaginativa como método de afirmación del ser y como actuación crítica respecto del archivo autobiográfico. Lo que Jodorowsky dispone como un cuadro operatorio que involucra al teatro, el happening, y la magia ritual, como un modo de desactivar las relaciones estancas entre autor-actor-espectador y de producir no en el teatro sino en la vida; Cuqui lo re-dispone en un ejercicio de autobiografía psicomágica.

En septiembre de 2008 Cuqui publicó KIKI, un diario íntimo en el cual documentó sus encuentros sexuales como parte de un proyecto literario, artís-

\footnotetext{
17 Ibídem, p. 5.

18 Ibídem, p. 7.
} 
tico y psicomágico. Este registro circuló a través de 40 ejemplares del diario y constituyó una primera fase de actuación del nombre Kiki como potencialidad creativa, crítica, erótica y esotérica. Cuatro años después, la segunda entrega de $K I K I$, pone al proyecto en una nueva posición: Cuqui interpela el presente de la escritura en el cual firma y crédito dan lugar a la identidad que se construye; indaga en la temporalidad performática del acto autobiográfico y psicomágico, a una revisión crítica del pasado (la Metagenealogía jodorowskiana) y de la literatura como archivo del presente.

El acto psicomágico que orienta las acciones de la escritora está vinculado a poner en crisis el "nudo incestuoso del yo" 19 a través del ejercicio de mantener relaciones sexuales con extraños, involucrándose alternativamente con partenaires, clientes, y búsquedas románticas diversas. Uno de los epígrafes que introducen $K I K I 2$, menciona que un maestro le indica a dos de sus discípulos misiones distintas: al primero le ordena acostarse con una mujer distinta cada día durante un año; y al segundo, hacerlo solamente una vez en ese mismo año. Cuqui ofrece esta clave para comprender que la acumulación de registros de citas y mensajes, el reparto de folletos de convite sexual con el número telefónico personal, la auto-oferta en sitios web con anuncios de acompañantes y de búsqueda de pareja, formaron parte integral de una experiencia artística, erótica y psicomágica mediante la cual el devenir-Kiki repone y re-dis-pone el propio derrotero en un ejercicio autobiográfico que tiene como objetivo ejercer un acto crítico de sí. El diario de Kiki apunta:

Jodorowsky dice que ser promiscuo es síntoma de tener un nudo incestuoso: "salgo con todos para no salir con nadie y ser de mis padres" pero creo que hay otra cuota no pensada, la del egoísmo, la de satisfacer mis necesidades y que si huyo de un solo hombre es para no ser como mis padres y no tener la responsabilidad de una familia. Entonces, como diría Jodor, soy igual a mi familia por oposición. ¿Y qué? Prefiero ser opuesta, pero no estar con niños y trabajando para mantenerlos. Lo opuesto me cae bien, muy bien. ${ }^{20}$

${ }^{19}$ JODOROWSKY, Alejandro; COSTA, Marianne. Metagenealogía. Buenos Aires: Sudamericana, 2011, p. 431.

20 CUQUI. KIKI 2. Cosquín: Editorial Nudista, 2012, p. 6. 
09/02 (02:50 am. Insomnio)

Por el momento no quiero tener pareja, así que el nudo incestuoso quedará ahí. Me da mucha bronca que los varones se acuesten con muchas personas y yo no, así que tener una pareja, para mí, sería una castración.

Sí quiero ligarme las trompas.

(Tipo 7:30 am)

Con respecto al nudo incestuoso, hay que tener en cuenta que para mí lo de ir a tirar papelitos para buscar chicos, lo de publicar avisos en Internet es "sembrar", no "pedir".

Jodorowsky dice que una de las características de ser adulto es la de sembrar y ésta la de ir superando el nudo incestuoso. ${ }^{21}$

Hoy caí en que mi cliente porteño me trató como a una puta porque le dije que era eso. Me trató tal cual le dije que yo era. Sin embargo, todo el tiempo me seguí comportando como artista, quizás como tarotista, porque eso es lo que yo pienso que soy.

Les tengo que decir a los varones qué soy y así me van a tratar.

Si les digo que soy una gorda fea, así será. ${ }^{22}$

La interpelación estética, psicomágica y política de Cuqui sobre la adjetivación de sí, produce una crisis respecto de imágenes asociadas a visibilidades tolerables y controlables, para provocar disidencias que obliteran las condiciones del insulto. ${ }^{23}$ Silvia Delfino ha referido que este tipo de prácticas de experimentación entre erotismo, lenguaje y deseos políticos, son parte de un doble movimiento que, al tiempo que niega aceptar las prescripciones de cualquier modo de normalidad, produce disidencias que acusan "la especificación de los modos históricos del menosprecio presentes en la

${ }^{21}$ Ibídem, p. 11.

22 Ibídem, p. 9.

23 El 3 de mayo de 2013, en el marco del Ciclo de lectura Los mudos, coorganizado por la Editorial Funesiana y Editorial Nudista, en la ciudad de Buenos Aires, Cuqui montó una performance de visibilización de la violencia de los estigmas. Semidesnuda frente a un micrófono, leyó las respuestas a sus avisos publicitados en una página web destinada a citas, escorts y masajistas de Córdoba. La performer refirió que su lectura, fragmentos de KIKI 2, eran de verdad producto de intervención real en el espacio digital y en los intercambios con hombres que consumen efectivamente estos sitios. El extracto seleccionado compuso imágenes en las que la mirada del otro sobre el propio cuerpo y devenir actúan como atribuciones violentas, como etiquetas o marcajes que el propio ritual psicomágico viene a poner en cuestión: "gorda fulera", "no tenes espejo? porque no pisas tierra?", "no sos linda", "sos orible", "bagallo" (CUQUI. KIKI 2, op. cit., p. 25-26). 
lengua." 24 En "Metonimia del abandono en el excentricismo de un exacto. La performance en forma de oración"25, Charlotte von Mess, otro de los heterónimos, dice de Kiki:

KIKI 2 es el resultado toulouse-lautrequiano del sentir en el cuerpo de Cuqui. En una época distinta a la bella, se pasea con su gordura amada en los óleos azules por Renoir, en un mundo que la desprecia. Sin contar su tatuaje de fuego en la cara, en memoria de las brujas quemadas en la Inquisición, que es mal visto en las pieles peelingzadas. ${ }^{26}$

De esta manera, las distintas intervenciones de Cuqui, de actuación, registro, edición y revisión de su performance, acontecen como ritual transformador respecto de la construcción del propio cuerpo en la tensión memoriaolvido, como una forma de desarticular etiquetas, no repetir lo pasado sino lo que de él va al futuro, volver extraños los actos aprendidos, des-habituar el gesto devolviéndolo a otro uso potencial, devolviéndolo al uso de otro nombre, en el gesto de inscribir otro nombre.

Mediante la Psicomagia y la Metagenealogía, disciplina de concientización de las potencialidades y desafíos del propio árbol genealógico desarrollada por Jodorowsky y Marianne Costa, Cuqui no solo trabaja con legados e

${ }^{24}$ DELFINO, Silvia. Introducción. In: Aventuras. Nuevas incursiones en el imaginario gay. Buenos Aires: Belleza y Felicidad, 2001, p. 6.

25 Este texto apareció en el marco de la presentación del libro KIKI 2 organizada por Editorial Nudista el 7 de diciembre de 2012, en la Ciudad de Córdoba. En esa oportunidad Cuqui realizó una performance interviniendo el espacio con las letras de su heterónimo, cubiertas con imágenes pornográficas masculinas, fotografiándose con los participantes de la presentación. La performer estaba vestida con un traje confeccionado con las mismas láminas pornográficas y se paseaba con un chupetín con forma de pene, repartiendo copias del texto de Charlotte von Mess. Entre abril y mayo de 2013, en la Exposición de artistas premiados en las Bienales de Arte Emergente 2001-2003-2005 del Centro Cultural España Córdoba, la propuesta de Cuqui fue la proyección de dos sesiones de imágenes desarrolladas por la artista con motivo de KIKI 2 (la primera sesión en 2009, compuso un álbum de la obra HABITABLE del artista Fabhio di Camozzi, y del booktrailer realizado por Myler Moss; la segunda sesión en 2012, obra en co-autoría de Cuqui y Juan Cruz Sánchez Delgado, con la que se desarrolló el arte de tapa y apéndice de la edición de Editorial Nudista), acompañadas de la exhibición del objeto-libro y del texto de von Mess plotteado en la pared de la sala de exposiciones.

${ }^{26}$ CUQUI [Charlotte von Mess]. Metonimia del abandono en el excentricismo de un exacto. La performance en forma de oración. 2012. 
imposiciones de su propio linaje, sino también los de la literatura sometiéndola licenciosamente a un trabajo psicomágico de "desprogramación" o "desactivación" de su "nudo incestuoso". Alberto Giordano, en La contraseña de los solitarios. Diarios de escritores, recupera para la lectura del "acto diarístico", la perspectiva de Michel Foucault sobre el conjunto de búsquedas y prácticas mediante las cuales el sujeto se transforma a sí mismo para acceder a la verdad. La escritura del diario puede asumir el trabajo de ascesis, "un camino para la experimentación performativa en el que el diarista pone a prueba la consistencia ética de lo que le pasa mientras ensaya transformaciones." 27 A propósito del llamado "giro autobiográfico en la literatura argentina actual”, también Giordano atendió a escrituras que devienen confesionales cuando aparece el problema de la verdad, deteniéndose en el trabajo de Pablo Pérez en Un año sin amor. Diario del SIDA donde el imperativo "tengo que escribir" que abre el diario cifra la equivalencia entre la producción textual y la producción de vida. En este caso se trata de un "aventurarse en la "propia" impersonalidad" 28 a través de un experimento clínico, de cuidado de sí por el cual se registran detalladamente los actos, ejercicios, pruebas y resultados respecto de la propia enfermedad. Cuando leemos el trabajo de Cuqui, la experimentación articula lo esotérico, lo escritural y lo erótico, como puesta en acto de consejos y misiones creativas. Mientras Pablo Pérez emerge del "tengo que escribir", Cuqui-KIKI del "hay que reprogramar." ${ }^{29}$ Los procedimientos reprogramadores justifican no sólo el atentado contra la tradición literaria, sino la asunción de una tradición alternativa que opta por discursividades esotéricas, de autoayuda y de taller de escritura, como modo de señalar en la literatura la salida de sí, el espacio del estallido de las singularidades, la noción de registro no como aquello que pasó, sino como producción de lo que pasará, la idea de archivo como composición y recombinación

27 GIORDANO, Alberto. La contraseña de los solitarios. Diarios de escritores. Rosario: Beatriz Viterbo, 2011, p. 36.

28 Ídem. El giro autobiográfico de la literatura argentina actual. Buenos Aires: Mansalva, 2008, p. 39.

${ }^{29}$ CUQUI; PERALTA, Juana. Jodorowsky 2. In: Plebella. Poesía actual. Buenos Aires: Cabaret Voltaire SRL, n. 21, 2010, p. 25. 
de imágenes, y la visibilización del acto excesivo que es el acto de escritura. Por ello, cuando Charlotte von Mess propone leer este diario como "performance oracional", revela una discusión que articula preguntas sobre la "postautonomización de la literatura" y la "realidadficción" 30, el acto de "testimoniar sin metáfora"31 y las "obras estriadas." 32

\begin{abstract}
Llevarse a la oración y no quedar en el formato visual (performance tradicional), podría tener que ver con la cantidad de imágenes pornográficas que abundan, en tanto la sobrevaloración de la sexualidad, donde no tendría mucho para aportar. Lo que ella aporta es verdad, mostrando las dificultades. ¿Por qué decidió hacer este nuevo autorretrato con palabras? ¿Por qué ser menos universal (las imágenes son pre-babélicas) con algo tan universal, cotidiano y sencillo como lo es el sexo? ¿Qué era lo que no podía registrar ópticamente para necesitar las palabras? ${ }^{33}$
\end{abstract}

Este diario re-dis-pone la escritura, al decir de Roland Barthes, como logotesis, es decir, como fundación de lengua. De esta manera lo que importa no es tan solo las aventuras eróticas del personaje, sino la forma en que el exceso hace hablar a la escritura, como operación de lectura que obliga a desplazar la "responsabilidad social del texto" 34 para problematizar que su

intervención social [...] se mide por la violencia que le permite superar las leyes que una sociedad, una ideología, una filosofía se otorgan para ser acordes consigo mismas, es un hermoso movimiento de inteligibilidad histórica. Este exceso tiene un nombre: escritura. ${ }^{35}$

30 Cf. LUDMER, Josefina. Aquí América Latina. Una especulación. Buenos Aires: Eterna Cadencia, 2010, p. 43; Literaturas postautónomas 2.0. In: Revista $Z$ Cultural. Rio de Janeiro: PACC/UFRJ, ano IV, n. 1, 2007; Literaturas postautónomas. In: CiberLetras. Revista de crítica literaria y de cultura. New York: Lehman College/CUNY, n. 17, jul. 2007.

31 KAMENSZAIN, Tamara. La boca del testimonio. Buenos Aires: Norma, 2007, p. 119-162.

32 GARRAMUÑO, Florencia. La experiencia opaca. Literatura y desencanto. Buenos Aires: FCE, 2009, p. 18.

${ }^{33}$ CUQUI [Charlotte von Mess]. Metonimia del abandono..., op. cit.

${ }^{34}$ BARTHES, Roland. Sade, Fourier, Loyola. Trad. Alicia Martorell. Madrid: Cátedra, 2010, p. 16.

35 Ibídem, p. 17. 
Particularmente KIKI 2 se sostiene excesivamente en el acto de escritura, en un ejercicio que consiste no en la sugestión o la metáfora (la erótica) sino la gramática o combinatoria de imágenes que se suceden en posturas, operaciones, figuras y episodios (la retórica). Cuando se narran los actos sexuales no hay erotismo en el sentido occidental del strip-tease sino como en el arte del tarot, la "tirada sexual" es una combinatoria de unidades o arcanos que "acontecen" sobre la mesa. Es una escena o cuadro montado según un orden vinculado a: una retórica de la preparación o búsqueda del acontecimiento desarrollada mediante el sistema de "sembrado" de volantes y anuncios en internet; del contrato de encuentro clasificado según medio telefónico o vía correo electrónico; del encuentro sexual ("P la primera cita le pido al chico q traiga 3 pelis d trror d mi elección y las vems dsnuds en la kma"36) como modo de organizar las acciones: el desnudo, las películas, el masaje, los alimentos. Una escena o cuadro montado en relación con una estructura de la narración que se reitera, describiendo primero imágenes del acto sexual y posteriormente documentando la modalidad del contrato de encuentro como forma de trasposición del esquema misión-acción; con clasificaciones discursivas de los partenaires vinculadas al protocolo del encuentro comprendido como pauta o regla: según sean clientes o amantes, según el compromiso para llevar o no las películas acordadas, según la funcionalidad en la misión metagenealógica en relación con atributos físicos (rubios, castaños, morochos) y origen (norteños, extranjeros) que permitan poner en crisis o no el "nudo incestuoso"; y finalmente vinculado a la construcción de la autoimagen como figura combinatoria en relación con retratos retóricos: según el tipo de preservativo elegido por ella, según la posiciones alcanzadas en la performance sexual, según lo que le pasa al cuerpo después del sexo, y según los nombres de los partenaires en relación con el yo (si su nombre es una etiqueta social, un arquetipo, un nombre de pila realista o una declarada invención). Si Cuqui monta escenas a través de una técnica combinatoria es porque reconoce mediante el tarot que cada carta expone un carácter episódico en el

${ }^{36}$ CUQUI. KIKI 2, op. cit., p. 56. 
marco de una narración más amplia que se organiza en función de una disposición de elementos sobre la mesa de lectura. El tarot tiene una estructura y una composición, al tiempo que es un "acontecimiento" vinculado al azar como aparición e irrupción. Es un dispositivo y un cuadro que se dispone en relación con el problema del presente y del origen, que convierte al diario en un interrogante acerca del archivo (metagenealógico, literario), del arcano (la imagen, el episodio), y del arconte (la economía, la organización y administración como modo de la escritura).

KIKI es el tarot de Cuqui, a través del cual monta de forma estructurada el acto sexual, mediante el cual combina las opciones discursivas del yo en función de los episodios, y con el que compone y descompone el propio árbol genealógico y literario como si fuera una tirada de cartas, una disposición de imágenes. En este sentido, es posible arriesgar que KIKI funciona como "El Mago", el primer arcano, el origen de la recombinación, la posibilidad de dar lugar al origen en el futuro, en las re-disposiciones de los elementos sobre la mesa. KIKI 2 por su parte, funciona como "La Sacerdotisa", el segundo arcano, la mujer con el libro, la lectora y escritora, quien ha reconocido su tránsito por la imagen de maga y ahora sabe que su poder se ejerce en la recombinación una y otra vez del deseo, el yo, y la escritura. ${ }^{37}$

CUQUI Y LA PROMESSA. LA TEMPORALIDAD DEL DUELO

Jorge Panesi, en "El precio de la autobiografía. Jacques Derrida, el circunciso", revela el correlato entre el acto de escritura autobiográfica y la estructura del duelo, como formas de la separación y escisión fundamental. La

37 A propósito de la autofiguración como Sacerdotisa o Papisa, cabe mencionar el "Acto Poético Colectivo. Sacerdotisas en la Catedral" llevado a cabo el 7 de mayo de 2011 en la explanada de la Catedral de Córdoba por MILISENDRA MILLARMINA, colectivo de artistas dedicadas a la investigación, experimentación y producción en lenguajes artísticos, con el objetivo de crear "Actos Poéticos Colectivos, Sanadores y propulsores de una toma de Conciencia y una elevación de la misma". El colectivo estuvo conformado por Cuqui, Marina Badino (pedagoga y directora teatral) y Verónica Montiel (actriz, pedagoga y directora teatral). El acto fue una reapropiación de la propuesta de psicomagia social "Mujeres vestidas de Papisas en el Vaticano" de Jodorowsky. 
autobiografía asumiría la forma de una entrega, en la que el yo se ofrece como don cuyo precio y cuya aceptación desconoce, entregándose al desconocido o a lo desconocido. El yo se ofrece dando "el teatro prefabricado de un duelo, y lo que me viene del pasado como regalo (como 'presente' decimos en español), tiene la estructura del duelo, viene al presente marcado por la ausencia."38 Es la manifestación de la "economía fúnebre" de la escritura, como ceremonia que devela que el nombre propio es el nombre de un muerto. Inscribir el nombre de un muerto, ha sido para Cuqui otra forma de hacer visible el desfasaje temporal de todo don o presente. 39

La Poesía completa (2009-2010) de Natsuki Miyoshi, que reúne Cisne de hierro, Nepiso Azulario, Informes a la crema. Libro basado en hechos reales, Deile enikirilla conntas deery Escaleras, es otro de los dones de Cuqui. Natsuki Miyoshi es la firma que Cuqui actuó entre 2009 y 2010, y los cinco libros que componen las obras completas fueron escritos durante ese periodo. Las discusiones acerca de la firma y la datación se articulan al problema del acto psicomágico, en tanto que inscripta a la temporalidad abierta por el nombre se halla la ejecución de cinco rituales de expiación de la escritura y sanación de los lectores. ${ }^{40}$

Con Natsuki, Cuqui interrumpe por deceso, un nombre propio, y con ello, clausura un proyecto de escritura. En tal interrupción, puede describirse, siguiendo a Paul De Man, un doble movimiento de huida y queda que hace a la forma de la prosopeya: la necesidad de fuga respecto de la tropología del sujeto y de una simétrica necesidad de retorno o inscripción de la huella de un sujeto en un modelo lapidario, de epitafio. Nada hay en la prosopeya que

38 PANESI, Jorge. Críticas. Buenos Aires: Norma, 2000, p. 99.

39 Cf. DERRIDA, Jacques. El tiempo del rey y Locura de la razón económica: un don sin presente. In: Dar (el) tiempo. Trad. Cristina de Peretti. Barcelona: Paidós, 1995.

40 El 17 de setiembre de 2011, en el marco de la presentación del libro Informes a la crema. Libro basado en hechos reales de Natsuki Miyoshi, editado por el sello independiente y alternativo La Tía, se realizó un acto de psicomagia que involucró a la escritora-performer y a los asistentes y lectores. La invitación a la presentación, que tuvo lugar en Dadá Mini, un bar en el barrio Güemes de la ciudad de Córdoba, adoptó la forma de consigna de participación, llamando a los lectores a llevar telas blancas, talco, recipiente, y pintura dorada. Con estos elementos se materializó el acto psicomágico. 
suponga identidad o semejanza entre lo que carece de voz o rostro y aquello que se propone como su máscara. Natsuki o Cuqui, ambos nombres están atravesados por la interpelación acerca de la urgencia constructiva de dar orden al vacío deformado de la historia de quien cuenta de sí misma. Nombrándose, la tensión que inscribe la firma de quien ha muerto, se vuelve en presente, un acto fundador y de inscripción, es decir, un acto de archivo ${ }^{41}$, una modalidad de la entrega, de la promesa y el compromiso. Con la firma se entabla un acto de lenguaje y de escritura consistente en la apertura del vivir del propio crédito. La escritura de Natsuki interpela la idea de la vida como prejuicio, es decir, la de la anticipación de un fallo verificable solo cuando el portador del nombre ha muerto, en tanto que los asuntos de contrato, deuda y crédito retornarían al nombre, aunque no se sepa a quién: Cuqui, Natsuki, Karen Smith, Charlotte von Mess, a cuentas de lo desmesurado del crédito. En todo caso, la inscripción del heterónimo es siempre un acto de potlatch: la escritura miyoshiana es ofrenda ritual, sacrificial, en tanto deja sus poemarios reunidos como cadáver, y en tanto presentificación de la mortaja y la exasperación de ausencia: "Estuvo satisfecha con su tiempo impasse, / ahora debe abandonar el cuerpo, / definitivamente dejar esa flor hermosa, irse."42 Panesi se preguntaba, sobre la "substancia textil” y "tejido caído" que hace a la autobiografía en Derrida "¿Y qué hay de la autobiografía en todo ese teatro fantasmagórico, en todos esos velos?" 43 . El abandono del cuerpo miyoshiano, el acto fúnebre de dejarlo, doblemente: como cuerpo textual y como substancia textil que lo vela; revela el gesto que interpela la firma como una entrega, un don incalculable que abre crédito al mito. Natsuki se inscribe en el doble acto del duelo y del don de Cuqui, quien autobiográficamente se entrega como presente de tasa y aceptación desconocidas. Este acto cifra una operación mediante la cual la inscripción del nombre se debe a la posibilidad de la

41 Cf. DERRIDA, Jacques. Mal de archivo. Una impresión freudiana. Trad. Paco Vidarte. Madrid: Trotta, 1997.

42 CUQUI [Natsuki Miyoshi]. Poesía completa (2009-2010). Córdoba: Babel, 2012, p. 60.

43 PANESI, Jorge. Variaciones sobre la literatura: la inscripción autobiográfica. In: CRAGNOLINI, Mónica (comp.). Por amor a Derrida. Buenos Aires: La Cebra, 2008, p. 94. 
apertura, la indeterminabilidad, la no coincidencia, y a la diseminación. Por ello, Cuqui hace de Natsuki Misyoshi la clave de la promesa como performativo de los libros por venir, de la entrega al otro, de la supervivencia del nombre y el mito.

Bibliografía

AMÍCOLA, José. Estéticas bastardas. Buenos Aires: Biblos, 2012.

ANTELO, Raúl. 0 arquivo e o presente. In: Gragoatá. Niterói: EdUFF, n. 1, jul./dez. 1996, pp. 43-61.

BARTHES, Roland. Sade, Fourier, Loyola. Trad. Alicia Martorell. Madrid: Cátedra, 2010.

CRAGNOLINI, Mónica. Razón imaginativa, identidad y ética en la obra de Paul Ricoeur. Buenos Aires: Editorial Almagesto, 1993.

CUQUI. Entrevista para el Museo Caraffa. Inédito (gentileza de la autora). . [Natsuki Miyoshi]. Poesía completa (2009-2010). Córdoba: Babel, 2012. . [Charlotte von Mess]. Metonimia del abandono en el excentricismo de un exacto. La performance en forma de oración. 2012. Disponible en bitácora de vuelo. . KIKI 2. Cosquín: Editorial Nudista, 2012. KIKI. Córdoba: Huácala Capirote, 2008.

CUQUI; PERALTA, Juana. Jodorowsky 2. In: Plebella. Poesía actual. Buenos Aires: Cabaret Voltaire SRL, n. 21, 2010, pp. 23-29.

DELFINO, Silvia. La trivialidad de lo sublime. In: Ramona. Revista de artes visuales. Buenos Aires: Fundación Start, n. 18, 2001, pp. 78-82.

. Introducción. In: Aventuras. Nuevas incursiones en el imaginario gay. Buenos Aires: Belleza y Felicidad, 2001.

DERRIDA, Jacques. Otobiografías. La enseñanza de Nietzsche y la política del nombre propio. Trad. Horacio Pons. Buenos Aires: Amorrortu, 2009.

Mal de archivo. Una impresión freudiana. Trad. Paco Vidarte. Madrid: Trotta, 1997. Edición digital de Derrida en castellano.

. L'oreille de l'autre. Montreal: Claude Lévisque, 1982.

GARRAMUÑO, Florencia. La experiencia opaca. Literatura y desencanto. Buenos Aires: FCE, 2009. 
GIORDANO, Alberto. El giro autobiográfico de la literatura argentina actual. Buenos Aires: Mansalva, 2008.

La contraseña de los solitarios. Diarios de escritores. Rosario: Beatriz Viterbo, 2011.

JODOROWSKY, Alejandro. Psicomagia. Madrid: Ediciones Siruela, 2004.

JODOROWSKY, Alejandro; COSTA, Marianne. Metagenealogía. Buenos Aires: Sudamericana, 2011.

KAMENSZAIN, Tamara. La boca del testimonio. Buenos Aires: Norma, 2007.

LEGAZ, María Elena. Desde la niebla. Sobre lo autobiográfico en la Literatura Argentina. Córdoba: Alción, 2000.

LUDMER, Josefina. Aquí América Latina. Una especulación. Buenos Aires: Eterna Cadencia, 2010.

. Literaturas postautónomas 2.0. In: Revista Z Cultural. Rio de Janeiro: PACC/UFRJ, ano IV, n. 1, 2007.

. Literaturas postautónomas. In: CiberLetras. Revista de crítica literaria y de cultura. New York: Lehman College/CUNY, n. 17, jul. 2007.

NIETZSCHE, Friedrich. Ecce homo. Trad. Sergio Albano. Buenos Aires: Gradifco, 2007.

PANESI, Jorge. Críticas. Buenos Aires: Norma, 2000.

. Variaciones sobre la literatura: la inscripción autobiográfica. In: CRAGNOLINI, Mónica (comp.). Por amor a Derrida. Buenos Aires: La Cebra, 2008.

PEZZONI, Enrique. Fervor de Buenos Aires: autobiografía y autorretrato. In: El texto y sus voces. Buenos Aires: Eterna Cadencia, 2009, pp. 79-110.

RICOEUR, Paul. El conflicto de las interpretaciones. Ensayos de hermenéutica. Trad. Alejandrina Falcón. Buenos Aires: FCE, 2003.

ROSA, Nicolás. El arte del olvido y tres ensayos sobre mujeres. Rosario: Beatriz Viterbo, 2004.

VON STECHER, Pablo. Una lectura semiótico-discursiva del tarot y un estudio de caso. In: AdVersuS. Revista de Semiótica. Buenos Aires: IIRS, año IX, n. 22, jun. 2012, pp.151-165. 